Volume 8 No. 1 April 2021

Nationally Accredited No. 30/E/KPT/2018 Dated 24th October 2018

This work is licensed under a Creative Commons Attribution-NonCommercial 4.0 International License

\title{
Childhood Statelessness: Critiquing International Norms and Enforcement Strategies
}

\author{
Biju R K
}

Faculty of Law, University of Calicut, India

Email: rkb.rajamangalam@gmail.com

Submitted : 2020-09-01 | Accepted : 2021-04-26

\begin{abstract}
Over the past decade, there has been renewed interest in and commitment to resolving the endemic problem of statelessness, most clearly exemplified by the United Nations High Commissioner for Refugees' Global Action Plan to End Statelessness 2014-24, which sets out to end statelessness by 2024. Despite the plethora of recent attention to questions of citizenship, its converse, the problem of statelessness and its effect on children, has not been adequately investigated. This paper attempts to delineate the causes of childhood statelessness in particular and to analyze the international legal framework for reducing and preventing it. It examines how statelessness is created, how it persists and why it brings with it the deprivations it does. It then subjects the customary and modern international legal norms governing childhood statelessness and enforcement strategies at Global level to close scrutiny and identifies the clearly discernible drawbacks and road blocks. It concludes with suggestions, inter alia, to make the jus soli citizenship a mandatory default clause in the citizenship laws of every country, to further prioritize birth registration and data collection and to strengthen the $U P R$ process and reporting procedure.
\end{abstract}

Keywords: Childhood Statelessness, Citizenship, Jus Soli, Refugees.

\section{INTRODUCTION}

'Statelessness' refers to a situation where 'a person is not considered as a national by any State under the operation of its law'. ${ }^{1}$ In practical terms, statelessness

1 Article 1(1), Convention Relating to the Status of Stateless Persons, 360 U.N.T.S. $117 \quad(28$ September 1954). For details on the interpretation of Article 1(1) of the 1954 Convention, see, UNHCR, Guidelines on the Definition of "Stateless Person" in Article 1(1) of the 1954 Convention relating to the Status of Stateless Persons (20 February 2012).

2 'Nationality' is commonly used as a synonym for 'citizenship', referring to a specific type of legal means having no nationality ${ }^{2}$ and thus no legal connection ${ }^{3}$ (vinculum juris ${ }^{4}$ ) with any State or in other words, belonging to nowhere. Absence of such a legal bond makes a person a non-entity for purposes of 
law. ${ }^{5}$ This problem takes two conceptually distinct forms: (1) the lack of legal identity; and (2) the inability to prove the legal identity that one does have. ${ }^{6}$ The people who lack legal identity include both de jure and de facto stateless people. De jure stateless are those who have no legal nationality at all. De facto statelessness is the result of refusal of the State of nationality to afford protection to some of its nationals. Inability to prove the legal identity, on the other hand, arises where people who are legal citizens lack the documents necessary to assert their legitimate claim to citizenship. These are people whose birth, family affiliation, or connection to society is not registered or otherwise provable. They may, despite their possession of nationality and a legal status, find themselves effectively stateless. ${ }^{7}$ These three classes of people together constitute the stateless population of the world today.

There are currently more than twelve million stateless people around the world of which approximately one third are children. ${ }^{8}$ Children are the most vulnerable human beings with a special need for legal protection. But the human beings,

5 Paul Weis, 'The United Nations Convention on the Reduction of Statelessness' (1961) 11 International and Comparative Law Quarterly 1073.

6 Jacqueline Bhabha, 'From Citizen to Migrant: The Scope of Child Statelessness in the Twenty-First Century' in Jacqueline Bhabha (ed) Children Without a State - A global Human Rights Challenge (The MIT Press, 2011) 1.

7 Ibid.

8 Statelessness related statistics are not reported on a systematic basis, as States generally do not collect and publish precise data regarding stateless persons. The given figure is as reported in UNHCR's global statelessness statistics for 2017, published in June 2018 in its annual "Global Trends" report available at: <www.unhcr.org/globaltrends2017/.>. This figure may be unreliable due to difficulty of definition and identification of statelessness, but it provides a general picture of the problem. irrespective of whether children or adults, require a competent and powerful authority to oversee the protection of their rights and such authority is the State. Citizenship is the means by which any human being acquires and exercises her rights as a member of an organized political community known as the State. Without citizenship from anywhere, State protection is almost non-existent. ${ }^{9}$ That is the reason why authors like Hannah Arendt viewed the right to a citizenship as the 'right to have rights. ${ }^{10}$ Arendt, who herself was a stateless refugee for 18 years, believed that the supposed universalism of human rights could only be guaranteed through citizenship. Statelessness, she argued, was tantamount to the loss of all rights including the right to be a human. Though nationality does not, on its own, guarantee wellbeing or enjoyment of the constituent elements of a dignified human life, its absence is strongly correlated with serious rights violations and profound human suffering. ${ }^{11}$

Even though the right to citizenship, including that of children, is protected under international law, ${ }^{12}$ in the existing international legal regime it is still the

See also, Institute on Statelessness and Inclusion, The World's Stateless (December 2014) 6-7, 40-43 <http://www.institutesi.org/worldsstateless.pdf.>.

9 See, Frelick, B and M. Lynch, 'Statelessness: a forgotten human rights crisis', (2005) 24 Forced Migration Review 65. <https://www.fmreview.org/sites/fmr/files/FMRd ownloads/en/sudan/frelick-lynch.pdf>

10 Hannah Arendt, 'The Decline of the Nation-State and the End of the Rights of Man' in The Origins of Totalitarianism (The World Publishing Company, New York: 1962) 267. See also, Trop v. Dulles, 356 U.S. 86 (1958).

11 Jacqueline Bhabha, 'The importance of nationality for children' in Institute on Statelessness and Inclusion (ed.), The World's Stateless Children (Wolf Legal Publishers (WLP), 2017) 112.

12 The Universal Declaration of Human Rights (UDHR) provides a general right to nationality under article 15. The international human rights treaties - including the Convention on the Rights of the Child (CRC) and the International Covenant on Civil and Political Rights (ICCPR) - as well as 
plenary power of a sovereign State to define 'citizenship' for purposes of its domestic jurisdiction and to provide for the regulatory framework necessary for granting the same. ${ }^{13}$ In many jurisdictions the legal means ${ }^{14}$ to gaining citizenship is either too complicated or expensive. This renders children of migrants and refugees vulnerable to statelessness.

The importance of nationality for children overlaps but is not co-extensive with the importance of nationality for adults. ${ }^{15}$ If a child does not secure citizenship of a nation immediately upon or as soon as possible after birth, she may be left stateless with extremely severe consequences. Statelessness in children has much more impact than that has in adults for a child's early environment, physical, emotional and affective, has lifelong potential impacts on her wellbeing and functioning during adulthood. Stateless children, through no fault of their own, inherit circumstances which provide them only with animal existence ${ }^{16}$ and uncertain future, and surrounded by a sense of worthlessness. ${ }^{17}$ As pointed out in a study report of Youth Advocate Program International:

Lack of citizenship subjects children to significant threats to their safety and well-being. Children without official papers are vulnerable to abduction,

the Convention on the Reduction of Statelessness, provide particular norms with respect to the right to nationality for children.

13 Convention on Certain Questions Relating to the Conflict of Nationality Laws, opened for signature 12 April 1930, 179 LNTS 89 (entered into force 1 July 1937) art 1.

14 State's legal instruments related to nationality can be the Constitution, a Presidential Decree or a citizenship Act and the legal means to gaining citizenship include the procedure prescribed thereunder.

15 Above $\mathrm{n} 11$.

16 'To be stripped of citizenship is to be stripped of worldliness; it is like returning to a wilderness as cavemen or savages ...they could live and die without leaving any trace.' (Arendt, above n 6) sale and trafficking, illegal adoption, and sexual exploitation. Many more are living in slave-like conditions after being trafficked for labor or sexual purposes to other countries. Unable to prove their true ages with legal documentation, stateless children cannot legally prove that they are too young to work or to serve in the military. Many thousands of displaced, abandoned, abducted, lost and refugee children have been forced to participate as combatants in armed conflicts. ${ }^{18}$

In addition to these, statelessness is found to have a huge impact on the mental health of children and can lead to depression, alcoholism, domestic violence and suicide. ${ }^{19}$ Being stateless also means not being able to access many other basic rights available to citizens. For stateless children, medical care may be less readily available or more costly than for others. Children without birth certificates cannot be legally vaccinated in at least 20 countries. $^{20}$ Education is usually limited or unavailable for stateless children. Moreover, left unresolved, childhood statelessness will create new and insurmountable roadblocks for children as they move from childhood to adolescence and adulthood.

Despite the numerous international instruments providing for the right to

17 Feeling expressed by a stateless woman named Chen as cited in Philippe Leclerc and Rupert Colville, 'In the shadows', (2007) 147 Refugees 6. $<$ https://www.unhcr.org/enie/publications/refugeemag/46d2e8dc2/refugeesmagazine-issue-147-excluded-strange-hiddenworld-stateless.html>.

18 Sarah Aird et al., Stateless Children - Youth who are without citizenship (Youth Advocate Program International, 2002) 7.

19 Constantin Sokoloff and Richard Lewis, Denial of Citizenship: a challenge to human security (European Policy Centre, 2005) 22.

20 Maureen Lynch and Melanie Teff, 'Childhood statelessness', (April 2009) 32 Forced Migration Review 32. 
nationality of a child, including the Convention on the Rights of the Child (CRC), ${ }^{21}$ the International Covenant on Civil and Political Rights (ICCPR), ${ }^{22}$ and the Convention on the Reduction of Statelessness, ${ }^{23}$ the problem of childhood statelessness continues to grow gradually. The status of children who are stateless or atrisk of statelessness has become a critical humanitarian issue, especially as there appears to be no resolution to this problem until present. There is general consensus that preventing statelessness is better than trying to resolve statelessness that has already arisen. This involves identifying the causes of statelessness and prescribing binding legal norms for its immediate reduction and ultimate eradication. Thus, this paper seeks to analyze, in the context of the global campaign to end childhood statelessness by $2024,{ }^{24}$ the principal circumstances in which children find themselves without any nationality and to critically evaluate the adequacy and efficacy of existing international norms relating to the right of every child to a nationality. This paper analyzes the question as to how and on what principle can it be legally ensured at the international level that children are provided with a nationality at birth.

\section{LEGAL MATERIALS METHODS}

AND

The methodology adopted in this paper is the normative juridical method. It is also analytical, descriptive and qualitative. The data utilized for this doctrinal study is based on primary and secondary sources. Primary

\footnotetext{
Article 7.

Article 24 (3).

Articles 1 to 4 .

24 In October 2013, the UN High Commissioner for Refugees called for the 'total commitment of the international community to end statelessness.' The Global Action Plan to End Statelessness: 2014 -
}

sources are relevant international legal instruments including conventions, customary norms as evidence of general practice accepted as law, general principles of law recognized by civilized nations and case law. Such sources of primary authority which have been referred to include the Convention on Certain Questions Relating to the Conflict of Nationality Laws (1930 Hague Convention), Universal Declaration of Human Rights (1948), Convention Relating to the Status of Refugees (1951), Convention Relating to the Status of Stateless Persons (1954), Convention on the Reduction of Statelessness (1961), International Covenant on Civil and Political Rights (1966), American Convention on Human Rights, "Pact of San Jose", Costa Rica (1969), Convention on the Rights of the Child (1989), African Charter on the Rights and Welfare of the Child (1990), Covenant on the Rights of the Child in Islam (2005), European Convention on Nationality (1997), InterAmerican Program for Universal Civil Registry and the "Right to Identity" (2008), Prevention and Reduction of Statelessness and Protection of Stateless Persons in the Americas (2014) and relevant judgements of the International Court of Justice. Secondary sources include books, journals, and reports conducted by UN High Commissioner for Refugees (UNHCR) and non-governmental organizations (NGOs). Extensive survey of available literatures has been undertaken and upon careful and critical scrutiny of the same the conclusions have been drawn and presented followed by suggestions.

\footnotetext{
2024, developed in consultation with States, civil society and international organizations, sets out a guiding framework made up of 10 actions that need to be taken to end statelessness by 2024 . <https://www.unhcr.org/statelesscampaign2014/G lobal-Action-Plan-eng.pdf>
} 


\section{RESULT AND DISCUSSION}

\section{Causes of Childhood Statelessness}

A variety of reasons have been identified $^{25}$ as responsible for the steady increase in the number of stateless children. But it is to be noted that the causes of statelessness around the world are remarkably consistent. Foundlings left without a nationality because of the lack of familial ties or evidence of birthplace is one of the oldest statelessness problems which States have sought to address by concluding international agreements. ${ }^{26}$ For a large number of children, statelessness is a direct result of their parents' stateless status, as many countries around the world observe a jus sanguinis nationality regime, whereby citizenship is granted only to those children whose parents are recognized citizens.

Another reason for statelessness is conflict between the citizenship laws of different countries. Membership in one State may carry a different set of rights and obligations, within a different legal framework, than does membership in another State. ${ }^{27}$ In cases of marriage between persons

25 See, for instance, Marilyn Achiron, Nationality and Statelessness: Handbook for Parliamentarians No 22 (Inter-Parliamentary Union/UNHCR, 2nd ed, 2014) 3, 3; Laura van Waas, Nationality Matters. Statelessness under International Law, (Antwerp/Oxford/Portland, Intersentia, 2008); Jacqueline Bhabha, 'From Citizen to Migrant: The Scope of Child Statelessness in the Twenty-First Century' in Jacqueline Bhabha (ed) Children Without a State A global Human Rights Challenge (The MIT Press, 2011; Kristy A Belton, 'Statelessness: A Matter of Human Rights' in Rhoda E HowardHassmann and Margaret Walton-Roberts (eds), The Human Right to Citizenship: A Slippery Concept (University of Pennsylvania Press, 2015) 31, 36-40; Jeffrey L Blackman, 'State Successions and Statelessness: The Emerging Right to an Effective Nationality Under International Law', (1998) 19 Michigan Journal of International Law 1141; Sophie Nonnenmacher and Ryszard Cholewinski, 'The Nexus between Statelessness and Migration' in Alice Edwards and Laura van Waas (eds), Nationality and Statelessness under of different nationalities, conflict can arise between nationality laws, leaving children stateless. ${ }^{28}$ Again, the hitherto unprecedented scale of migration of families across the borders, especially forced or undocumented migration, adds complexity to the question of access to citizenship. Many governments fail to realize their obligations towards forced migrant children. ${ }^{29}$ The nationality laws of some States terminate citizenship upon completion of continuous residence abroad for a specified period, while some other States stipulate that nationality cannot be transmitted indefinitely to successive generations living abroad. In these situations, children of later generations face the risk of statelessness which assume greater proportion if the host State does not grant jus soli citizenship to children born in its territory. Technical flaws in nationality laws can also cause statelessness, for example when a person is required to renounce her original nationality before being able to apply for a new nationality. In such cases, if naturalization does not occur and there are no other protections in place, she is left stateless.

International Law (Cambridge University Press, 2014) 247, 249-50; Paul Weis, Nationality and Statelessness in International Law (Kluwer Academic Publishers Group, Dordrecht: 1979) 215; Gerard-René de Groot, Children, their right to a nationality and child statelessness (Cambridge University Press 2014); Michelle, Foster et al, 'Part One: The Prevention and Reduction of Statelessness in Australia - An Ongoing Challenge' (2017) 40 Melbourne University Law Review 456, 458.

26 The 1930 Hague Convention on Certain Questions relating to the Conflict of Nationality Laws had already set out, under Article 14, a safeguard for children of unknown parents and foundlings.

27 Jeffrey L. Blackman, 'State Successions and Statelessness: The Emerging Right to an Effective Nationality Under International Law', (1998) 19 Michigan Journal of International Law 1141.

28 This is in spite of the provisions of the 1957 Convention on the Nationality of Married Women.

29 Jo Boyden, 'The Statelessness of the World's Children', (2007) 21 Children \& Society 237. 
Plugging such gaps in laws and policies that may cause statelessness at birth among children has been pointed out as a key area to be addressed in order to prevent statelessness. $^{30}$

Sometimes children are stateless because they have difficulties in proving their links to a State. Lacking birth registration and birth certificates creates such a risk. Children may not be registered because parents fear drawing attention to their own status. A child can also become stateless when a birth record is destroyed or lost and there is no other means to link them with a particular country. ${ }^{31}$ Problems also occur on a large scale in practice when the father refuses to recognize the child as his own or to take action to register the child with the authorities of his country.

Discrimination, ${ }^{32}$ for example, on the basis of ethnicity, race, religion or gender, is yet another major cause of statelessness globally. The UN Human Rights Committee has consistently stressed the importance of non-discrimination in addressing the right of every child to a nationality. ${ }^{33}$ In this regard, gender inequality is most serious where discriminatory nationality laws deny mothers the right to pass their nationality on to their

30 UN High Commissioner for Refugees and ASEAN Intergovernmental Commission on Human Rights, Report of the ASEAN Regional Workshop on Statelessness and the Rights of Women and Children (19 November 2011) 11. <http://www.refworld.org/docid/50f674c42.html>

31 Maureen Lynch and Melanie Teff, 'Childhood statelessness', (April 2009) 32 Forced Migration Review 31.

32 For a legal definition of 'discrimination', see, para 7, UN Human Rights Committee, General Comment No. 18: Non-Discrimination, UN Doc CCPR/C/GC/18 (10 November 1989).

33 See for instance, para 8, Human Rights Committee, General comment No. 17: Article 24 (Rights of the child) (29 September 1989).

34 'In many places, gender-based discrimination disproportionately impacts individuals from marginalised ethnic or religious groups, especially when the authorities have discretion to grant children. ${ }^{34}$ This is a particular problem in about 25 countries around the world, ${ }^{35}$ and can also arise when a child is born to parents from different countries, or where the father is unknown ${ }^{36}$ or refuses to acknowledge the child. As rightly pointed out by Catherine Harrington: ${ }^{37}$

States may have legitimate concerns regarding the acquisition of citizenship. However, such concerns can and must be addressed without resorting to discrimination, including on grounds of sex, as required under international human rights law. Unfortunately, many authorities and elected officials are unaware of their State's international legal obligations. ${ }^{38}$

Political rifts and conflicts leading to the establishment of new States may also create childhood statelessness. State succession can leave people without a nationality, for example where the original State of nationality dissolves leaving a person without the nationality of the new State. Solving existing cases of statelessness that have already been created by changes in political geography and forestalling new cases in the event of future situations of state succession are tough challenges that the

nationality to the children of women citizens only in "exceptional" circumstances' [Institute on Statelessness and Inclusion, The World's Stateless Children (Wolf Legal Publishers (WLP), January 2017) 497-98]

35 UN High Commissioner for Refugees (UNHCR), Background Note on Gender Equality, Nationality Laws and Statelessness 2020 (14 July 2020) 2.

36 For example, as a result of rape.

37 Campaign Manager of the Global Campaign for Equal Nationality Rights, an international coalition led by organizations including the Women's Refugee Commission, the Institute on Statelessness and Inclusion, and the Office of the United Nations High Commissioner for Refugees.

38 Catherine Harrington, 'Campaigning for gender equality in nationality laws' in Institute on Statelessness and Inclusion, The World's Stateless Children (Wolf Legal Publishers (WLP), January 2017) 499. 
international community faces in addressing statelessness. $^{39}$

In some countries, law may also not protect against statelessness in the context of adoption or surrogacy, or allow for the deprivation or loss of nationality of children. ${ }^{40}$ While there are countries without safeguards that protect against childhood statelessness, other countries have partial safeguards, conditional on the fulfilment of unreasonable criteria. Even in countries with full safeguards, implementation can be discriminatory and/or ineffective. ${ }^{41}$ Thus, from the foregoing it follows that broadly three types of childhood statelessness can be distinguished. Firstly, children who are the victims of conflict of laws or administrative malfunction; secondly, victims of directly discriminatory laws and policies and finally, children affected by state succession.

\section{Norms of Customary International Law on Statelessness}

It is true that States have the sovereign right to determine the policy, procedures and conditions for acquisition and termination of citizenship, but State sovereignty in relation to nationality matters is subject to certain limitations through norms set by international law. Nowadays, the scope of such limitations is on the increase and what was once conceded to be in the exclusive discretion of States has become the target of human rights activism. States have started perceiving statelessness as a broad human

39 Institute on Statelessness and Inclusion (ISI), The World's Stateless (Wolf Legal Publishers, January 2014) 24.

40 Institute on Statelessness and Inclusion (ISI), The World's Stateless Children (Wolf Legal Publishers (WLP), January 2017) 160.

41 Ibid.

42 According to Article 38 of the Statute of the International Court of Justice, "international custom, as evidence of a general practice accepted as law", is one of the sources of international law. rights issue rather than as a mere 'technical problem'. States are now obligated to prevent statelessness and to take actions to resolve existing cases. Such obligation to protect stateless persons and to reduce statelessness is derived not only from international instruments dealing explicitly with this issue but from norms of customary international law also.

Customary international law refers to international obligations arising from general international practices, ${ }^{42}$ as opposed to obligations arising from formal written conventions and treaties. It reflects the psychological need for pattern and regularity on the part of the States. ${ }^{43}$ In contrast to compliance by individuals with domestic laws on the ground of fear of the authority of law and sanctions, compliance with international law depends on the recognition by States that they should comply. Thus, it is the widespread and consistent State practice and opinio juris ${ }^{44}$ that constitute the corpus of customary international law. ${ }^{45}$ There are fundamental norms under customary international law evolved for tackling the problem of statelessness which are binding on all States. The prohibition qualifies as a norm of customary international law because it has been consistently viewed as a matter of concern for the international community as

43 Daniel M. Bodansky, 'The Concept of Customary International Law' (1995) 16(3) Michigan Journal of International Law 667.

44 Opinio juris denotes a subjective obligation, a sense on the part of a State, that it is bound by the norm in question.

45 International Law Commission, Identification of Customary International Law: Text of the Draft Conclusions Provisionally Adopted by the Drafting Committee, UN Doc. A/CN.4/L.872 (2016) 1. 〈http://legal.un.or/lc> 
expressed in various UNGA resolutions ${ }^{46}$ which raise presumption in favour of opinio juris. Many great scholars of public international law have also concluded that customary international law secured the right to a nationality and prohibited the creation of statelessness and that a person who is not otherwise a national of any State must be considered national of the State in which he was born. ${ }^{47}$

Apart from the above stated norms of 'right to a nationality' and 'duty to avoid statelessness', there is another principle of equal importance which is the 'norm of nondiscrimination'. The duty not to discriminate is the international human rights law principle of equal treatment that bears directly on the issue of nationality. The norm prohibits discrimination in law or in fact in any field regulated and protected by public authorities, which are imposed on States in regard to their legislation and the implementation thereof. Governmental actions, everywhere in the world, shall be in conformity with the norm of nondiscrimination. The emergence of the norm of non-discrimination in international law has been duly noted by the International Law Commission in its deliberations. ${ }^{48}$

International law is thus evolving on the issue of statelessness from the negative function of limiting the competence of States in the conferral of nationality towards the imposing of positive obligations on States to grant nationality in accordance with the genuine effective links of the persons concerned. Such affirmative obligations,

46 For example, see UNGA Res. 50/152, 51/75, 62/125, 63/149, 64/129, 65/193, 66/135, 67/149, $67 / 150$ etc.

47 William Thomas Worster, The Presumption of Customary International Law: A Case Study of Child Statelessness (December 21, 2017) 6. <http://dx.doi.org/10.2139/ssrn.3091912> developed during the past fifty years, find expression in the general norms of right to a nationality, duty to avoid statelessness, and nondiscrimination. The importance of the recognition of these principles as norms of customary international law lies in the fact that they will then bind the States without having the need for any contractual basis. ${ }^{49}$ But what makes the domestic application of a customary international norm problematic is that its evidentiary basis is so loose that it provides excessive discretion for States to claim violations by others or defences for themselves. The existence of consistent State practice and opinio juris, the objective and subjective elements necessary for constituting a customary norm is practically difficult to establish. Furthermore, where such a norm is applied by a court, it provides excessive discretion to the court. Many scholars therefore dismiss customary international law as increasingly irrelevant and prefer to have positive legislative instruments in place for effectively addressing the problem of childhood statelessness.

\section{Modern International Legal Regime Concerning Childhood Statelessness}

The evolution of international legal framework on childhood statelessness has been along two tracks: one to protect and assist those individuals who were already stateless, and the other to try to eliminate, or at least to reduce, the incidence of

48 Jeffrey L. Blackman, 'State Successions and Statelessness: The Emerging Right to an Effective Nationality Under International Law' (1998) 19(4) Michigan Journal of International Law 1141.

49 The limited number of States Parties to the 1954 and 1961 Conventions all the more underlines the importance of general human rights obligations relating to the right to a nationality. 
statelessness. $^{50}$ The 1930 Hague Convention, ${ }^{51}$ held under the auspices of the Assembly of the League of Nations, was the first international attempt to ensure that all persons have a nationality. ${ }^{52}$ The opening article of the Convention mandates that the States, while exercising their right to determine their citizens, shall conform to the relevant provisions of international law. ${ }^{53}$ The Permanent Court of International Justice (PCIJ) had, as early as in 1923, stated in its Advisory Opinion on the Tunis and Morocco Nationality Decrees that, 'the question whether a certain matter is or is not solely within the domestic jurisdiction of a State is an essentially relative question; it depends on the development of international relations. ${ }^{54}$ Nationality, which is in principle a subject matter within domestic jurisdiction, was thus held to be governed also by rules of international law to the extent of the limitations imposed on State discretion by obligations undertaken towards other States. It was this theme that was incorporated in the 1930 Hague Convention.

Subsequently in the post-war period, the 1948 Universal Declaration of Human Rights (UDHR $)^{55}$ which is now considered as customary law binding on all countries, ${ }^{56}$ declared under Article 15, out of the particular interest of the international

50 Marilyn Achiron, Nationality and Statelessness Handbook for Parliamentarians (Inter Parliamentary Union and UNHCR, $2^{\text {nd }}$ edn, 2014) 8.

51 Convention on Certain Questions Relating to the Conflict of Nationality Laws, opened for signature 12 April 1930, 179 LNTS 89 (entered into force 1 July 1937).

52 Above $\mathrm{n} 50$.

53 Article 1 reads: 'It is for each State to determine under its own law who are its nationals. This law shall be recognised by other States in so far as it is consistent with international conventions, international custom, and the principles of law generally recognised with regard to nationality.'

54 Advisory Opinion No. 4, Nationality Decrees Issued in Tunis and Morocco, (1923), Permanent community in declaring a minimum set of inalienable and indefeasible human rights, that everyone has the human right to a nationality and that no one shall be arbitrarily deprived of his nationality nor denied the right to change his nationality. Here it is noticeable that Article 15 of the UDHR does not prescribe the specific nationality to which a person is entitled. In order, therefore, to ensure that individuals are not deprived the rights associated with nationality, the international community designed two main treaties, namely the 1951 Convention relating to the Status of Refugees (1951 Refugee Convention) and the 1954 Convention relating to the Status of Stateless Persons (1954 Convention). The principles contained in these conventions have been further elaborated upon and reinforced by other treaties, jurisprudence, and state practice. $^{57}$

Since many of the refugees are stateless also, the interrelation between the two conventions is apparent. The provisions of the 1954 Convention are, in many respects, similar to those of the 1951 Refugee Convention. ${ }^{58}$ However, due to the special situation of refugees, the 1951 Refugee Convention contains specific reference to non-penalization for unlawful entry and to

Court of International Justice (7 February 1923) 23.

55 GA Res 217A (III), UN GAOR, 3rd sess, 183rd plen mtg, UN Doc A/810 (10 December 1948).

56 Sarah Aird et al, Stateless Children - Youth Who are Without Citizenship (Youth Advocate Program International, 2014) 3.

57 Carol A. Batchelor, 'Statelessness and the Problem of Resolving Nationality Status' (1998) 10 International Journal of Refugee Law 156-182, 156.

58 This is because the 1954 Statelessness Convention was originally intended to be a Protocol to the 1951 Refugee Convention and both the conventions address similar rights with a few distinctions. 
the principle of non-refoulement. ${ }^{59}$ These principles are not contained in the 1954 Convention. As such, if a person qualifies for both refugee and stateless status, the State is expected to apply to her the more favourable provisions of the 1951 Refugee Convention. ${ }^{60}$

In 1950, the International Law Commission (ILC) commenced the process of drafting what emerged later as the 1961 Convention on the Reduction of Statelessness (1961 Convention). ${ }^{61}$ The 1961 Convention is the only universal instrument that elaborates clear, detailed and concrete safeguards to ensure a fair and appropriate response to the threat of statelessness. The purpose of the Convention, as set out in its Preamble, is 'to reduce statelessness by international agreement'. It obliges contracting States to grant nationality to persons born in their territory who without such nationality would not be recognized by any State as a national, and would thus be 'otherwise stateless'. It gives contracting States several alternatives including automatic acquisition of its nationality upon birth in its territory, acquisition of nationality at an age determined by domestic law or acquisition on application if certain conditions are fulfilled. It requires States parties to adopt nationality legislations that

59 Non-refoulement is a principle of international law which prohibits States from expelling or returning a refugee or asylum seeker to a territory where there is a risk that her life or freedom would be threatened on account of race, religion, nationality, membership of a particular social group or political opinion. (Article 33, Convention relating to the Status of Refugees, 1951).

60 Above n 52, 11.

61 Convention on the Reduction of Statelessness, opened for signature 30 August 1961, 989 UNTS 175 (entered into force 13 December 1975).

62 International Convention on the Elimination of All Forms of Racial Discrimination (21 December 1965) 660 UNTS 195 (entered into force 04 January 1969). reflect prescribed standards relating to the acquisition or loss of nationality. But it neither prohibits the possibility of deprivation of nationality under certain circumstances, nor requires States to grant citizenship to all currently stateless persons.

The 1965 Convention on the Elimination of All Forms of Racial Discrimination, ${ }^{62}$ obliges States to "guarantee the right of everyone, without distinction as to race, colour, or national or ethnic origin, to equality before the law," particularly in the enjoyment of several fundamental human rights, including the right to nationality. ${ }^{63}$ The right of every 'child' to acquire a nationality has been specifically set out for the first time in the 1966 International Covenant on Civil and Political Rights (ICCPR). ${ }^{64}$ Article 9 of the 1979 Convention on the Elimination of All Forms of Discrimination against Women $(\mathrm{CEDAW}){ }^{65}$ addresses discrimination against women in nationality laws, one of the major cause of statelessness.

The 1989 Convention on the Rights of the Child (CRC) ${ }^{66}$ which has been ratified by almost all States, ${ }^{67}$ defines a 'child' as 'every human being below the age of eighteen years unless under the law applicable to the child, majority is attained earlier. ${ }^{68}$ With regard to nationality, it contains three important

63 Ibid Article 5.

64 International Covenant on Civil and Political Rights (ICCPR) (1966) 999 UNTS 171 (entered into force 23 March 1976) Article 24. Article 26 of the ICCPR also sets out a non-discrimination clause which applies very broadly, including to nationality legislation and how it is implemented.

65 Convention on the Elimination of All Forms of Discrimination Against Women (1979), 1249 UNTS 13 (entered into force 3 September 1981).

66 Convention on the Rights of the Child, (1989) 1577 UNTS 3 (entered into force 02 September 1990).

67 Except USA and Somalia.

68 Ibid Article 1. 
articles - articles 2, 7 and $8 .^{69}$ Read with Article 24 of the ICCPR, these provisions imply that it is not acceptable to postpone the right to acquire a nationality until a person reaches the age of eighteen years. ${ }^{70}$ Here also, it is particularly important to note that, neither the ICCPR nor the CRC indicate which nationality a child may have a right to, nor do they guarantee that the nationality is acquired at birth. Jaap Doek, former Chairperson of the UN Committee on the Rights of the Child (CRC Committee) has commented that 'the drafters could have adopted the jus soli approach rather than providing that 'all necessary measures are taken to prevent the child from having no nationality. ${ }^{, 71}$

In 1996, the UN General Assembly recognised the prohibition of arbitrary deprivation of nationality as a 'fundamental principle of international law. ${ }^{72}$ From 1997 onwards, resolutions on 'Human Rights and the Arbitrary Deprivation of Nationality' have been adopted periodically by the

69 Article 2 stipulates that: 'States Parties shall respect and ensure the rights set forth in the... Convention to each child within their jurisdiction without discrimination of any kind, irrespective of the child's or his or her parent's or legal guardian's race, colour, sex, language, religion, political or other opinion, national, ethnic or social origin, property, disability, birth or other status.' Article 7 states that: 'The child shall be registered immediately after birth and shall have the right from birth to a name, the right to acquire a nationality, and, as far as possible, the right to know and be cared for by his or her parents.' Article 8 (1) provides that: 'States Parties undertake to respect the right of the child to preserve his or her identity, including nationality, name and family relations as recognized by law without unlawful interference.

70 Gerard-Rene de Groot, Children, their right to a nationality and child statelessness (Cambridge University Press 2014) 146.

71 Jaap Doek, 'The CRC and the Right to Acquire and Preserve a Nationality' (2006) 25 Refugee Survey Quarterly 26-32, 26.

72 UN General Assembly, Resolution 50/152: Office of the United Nations High Commissioner for Refugees (9 February 1996), para. 16.
Commission on Human Rights and the Human Rights Council. In addition to these global instruments, several regional instruments also contain provisions on the nationality rights of children to reinforce its legal basis. $^{73}$ Although the record of ratification of relevant international instruments varies, the great majority of States are parties to one or several of these treaties that guarantee the right to citizenship. Moreover, the right of every child to a nationality has also been recognized and further elaborated through the decisions of regional human rights courts and committees. $^{74}$

\section{Doctrinal Foundations of National Citizenship Regimes ${ }^{75}$}

Even though norms of customary international law as well as provisions of international legal instruments recognize the right to a nationality of all members of the human family including children, ascriptive and functional criteria for citizenship vary

73 For example, the 1969 American Convention on Human Rights; the European Convention on Nationality (1997); the African Charter on the Rights and Welfare of the Child (1990); Covenant on the Rights of the Child in Islam (2005); InterAmerican Program for Universal Civil Registry and the "Right to Identity" (2008); Prevention and Reduction of Statelessness and Protection of Stateless Persons in the Americas (2014) etc.

74 See, Inter-American Court of Human Rights case of Yean and Bosico v. Dominican Republic (8 September 2005, available at: http://www.refworld.org/docid/44e497d94.html.); the African Committee of Experts on the Rights and Welfare of the Child (ACERWC) case of Children of Nubian descent in Kenya $v$. Kenya (22 March 2011, available at: http://www.refworld.org/docid/4f5f04492.html.); the European Court of Human Rights case of Mennesson v. France [26 June 2014, available at: http://acerwc.org/?wpdmdl=8606 (FR).

75 The expression 'citizenship regimes' is used in the sense of institutionalized systems of formal and informal norms that define access to membership, as well as rights and duties associated with membership, within a polity. 
significantly across the world. Since it is still the State's prerogative to define its own citizenship, it is the domestic citizenship laws that currently determine which links between the child and the State should be reflected in the formal bond of citizenship. There is no common standard or fundamental principle in this regard. Generally, it can be seen that two sharply differing legal principles govern automatic citizenship-attribution rules in the present-day world: the jus soli (right of soil) rule of citizenship and the jus sanguinis (right of blood) rule. By the doctrine of jus soli, a person acquires citizenship of the country where she is born irrespective of the citizenship of her parents. By the doctrine of jus sanguinis, on the other hand, a person acquires the citizenship of her parents irrespective of the place of her birth. Thus, unlike the right of the soil, jus sanguinis is based on ethnic grounds rather than the territory. Naturalization is a third legal method for acquiring citizenship. It is the process of acquiring citizenship after birth. Whereas birthright attribution of citizenship, either by way of jus soli or by jus sanguinis, is involuntary and ascriptive, naturalization is a voluntary process. It requires express consent of the individual and acceptance by the State to which she migrates.

International law does not express a preference for any one of the above principles for granting birthright citizenship over the other. ${ }^{76}$ Since researches have mostly been focused on various aspects of immigration policies and citizenship, a systematic analysis of birthright citizenship is lacking. But it is pertinently clear that it is in the 'best interests of the child' to acquire a nationality at or very soon after birth. So far

76 Indira Goris et al, 'Statelessness: what it is and why it matters' (2009) 32 Forced Migration Review 4. as regards the question as to which State bears the responsibility for granting nationality to a child born stateless is concerned, there is no single, definitive answer for the time being. Some States follow one rule almost to the exclusion of the other, and the ensuing conflict of laws create problems of statelessness among children. Some other States follow a hybrid of these principles which also may result in conflict, chaos and confusion. This points to the urgent need to have a uniform rule for fixing States' responsibility to grant nationality to stateless children.

According to the provisions of both the 1954 Convention and the 1961 Convention, the solution for statelessness is to look to the State with which the individual has a genuine and effective link. Such link may be birth on the territory, descent, residence or marriage to a national. ${ }^{77}$ However, the link should not be based on discriminatory grounds like race, colour, gender, religion or political opinion. When we consider which of the permissible links is the most effective one in ensuring that no child is left stateless, it seems jus soli is preferable to apparently ethnic jus sanguinis and other grounds. If we are concerned with providing children with the protections that come with citizenship status at birth, the most efficient way to do this is to grant them citizenship of the country where they are born, without exceptions.

The advantages of practicing such unconditional jus soli, with standard exceptions for children born to foreign diplomats or other State representatives and foreigners in transit, are manifold. Because newborns have no control over the actions of their parents, jus soli citizenship creates a

77 U.N. Secretary-General, Arbitrary Deprivation of Nationality: Report of the Secretary-General, U.N. Doc. A/HRC/10/34 (Jan. 26, 2009) para 62. 
guarantee that children will have some form of national citizenship they can call their own. No questions need be answered on behalf of the child about ethnicity, culture, or status. This eliminates the possibility of a child being victimized by a culture because of who or what her parents happen to be. Moreover, in view of the human rights obligations of States, the State within whose territory a child is born will have to ensure her fundamental human rights and for that purpose attribution of nationality would be desirable. Territorial birthright citizenship has the further benefit of allowing the children of unauthorized migrants to grow up and to participate fully in the life of their country of birth and to continue residence as citizens so as to make de jure statelessness comparatively rare. Another obvious scenario for which it is vital to have a provision for nationality by jus soli is where the parents are stateless. In that case, birth on the territory can provide a simple way to establish which State should provide citizenship.

In the Nottebohm Case, ${ }^{78}$ the International Court of Justice (ICJ) has confirmed that birth in a territory is one of the important connections underlying the 'genuine link' test for nationality. ${ }^{79}$ After conducting an elaborate survey of authorities, Worster, in his article published in $2019,{ }^{80}$ asserted that a specific norm has emerged under international law which

78 Liechtenstein v. Guatemala [1955] ICJ Rep 1 (6 April 1955).

79 William Thomas Worster, The Presumption of Customary International Law: A Case Study of Child Statelessness (December 21, 2017) <http://dx.doi.org/10.2139/ssrn.3091912>

80 William Thomas Worster, 'The Obligation to Grant Nationality to Stateless Children Under Customary International Law' (2019) 27 Michigan State International Law Review 441.

81 The use of the mandatory 'shall' in Article 1 of the 1961 Convention ("Such nationality shall be granted..."), indicates that a Contracting State requires the State where the child was born to grant nationality to it, if it would be otherwise stateless and no State has granted it nationality. It is also to be noted that the right of every child to acquire a nationality and the principle of the best interests of the child together create a presumption that States need to provide for the automatic acquisition of nationality at birth by an otherwise stateless child born in their territory, in accordance with Article 1(1)(a) of the 1961 Convention. Providing for a discretionary naturalization procedure for otherwise stateless children is not permissible under the 1961 Convention. ${ }^{81}$

\section{Enforcement Strategies at the International Level}

Statelessness is not merely a legal problem; it is a human problem. ${ }^{82}$ So far as children are concerned, the problem is bigger than 'just' a child rights issue and a range of strategies must be adopted as part of an effective international response. If every child has the right to a nationality, how is that right to be realized, how is nationality to be ascribed are the questions to be answered. Even though article 24 of ICCPR and other relevant provisions of international instruments guarantee the right to acquire a nationality, there is no specification by which time this right has to be implemented and what procedure is to be adhered to for enforcing the remedies guaranteed.

must grant its nationality to otherwise stateless children born in their territory where the conditions set forth in Article 1(2) and incorporated in their application procedure are met.

82 Carol A Batchelor, 'Statelessness and the Problem of Resolving Nationality Status' (1998) 10 International Journal of Refugee Law 156, 159. A similar observation can be found in Paul Weis, 'The United Nations Convention on the Reduction of Statelessness, 1961' (1962) 11 International and Comparative Law Quarterly 1073, 1090. 
Article 11 of the 1961 Convention on the Reduction of Statelessness provides for an agency to help individuals and States to clarify nationality issues and to advise on how to avoid the creation of statelessness. ${ }^{83}$ This role was subsequently assigned to the United Nations High Commissioner for Refugees (UNHCR) when the Convention came into force. ${ }^{84}$ The duties of the UNHCR with regard to statelessness include identifying cases of statelessness, reducing statelessness, preventing statelessness, and providing assistance to stateless persons. UNHCR's involvement may be triggered when there are indications that an individual or population could be stateless. UNHCR will generally also need to become involved where there is a risk of future statelessness due to such factors as gaps in legislation, administrative hurdles to acquisition or confirmation of nationality, or State succession. ${ }^{85}$ Where causes of statelessness relate to constitutional provisions or nationality legislation, UNHCR Field Offices can proactively provide advice on international standards and how they may be implemented at the national level. For this purpose, Field Offices may invoke the 1961 Convention and its obligations with State parties. In States which are not parties, the 1961 Convention can be used as a yardstick to identify gaps in nationality legislation and

83 Article 11 calls for the establishment of 'a body to which a person claiming the benefit of this Convention may apply for the examination of his or her claim and for assistance in presenting it to the appropriate authority'.

84 General Assembly resolutions 3274 (XXIV) and $31 / 36$ designated UNHCR as the body mandated to examine the cases of persons who claim the benefit of the 1961 Convention and to assist such persons in presenting their claims to the appropriate national authorities. Subsequently, the United Nations General Assembly conferred upon UNHCR a global mandate for the identification, prevention and reduction of statelessness and for the international protection of stateless persons. to advise governments on measures to prevent and reduce statelessness. In the specific case that a national constitution is being adopted or amended, Field Offices and other UN agencies may draw on the 2009 Guidance Note of the Secretary-General: United Nations Assistance to Constitutionmaking Processes. ${ }^{86}$ However, despite all these provisions, the actions of UNHCR are likely to be compromised by virtue of its status as an intergovernmental body that renders it subject to the twists and turns of political interests. For example, UNHCR can maintain a presence in any given country only through the invitation of the host government. ${ }^{87}$ These structural considerations limit significantly UNHCR's scope for action.

The UN Committee on the Rights of the Child (CRC Committee) also works closely with State Parties and UN Agencies, in monitoring the implementation of the Convention on the Rights of the Child (CRC) and its Optional Protocols. As the UN treaty body mandated to interpret and monitor States Parties' compliance with the CRC, the works of the CRC Committee is central to gaining a better understanding of States Parties' obligations under Article 7 of the CRC. Although the Committee has commented on relevant issues in all regions and across a range of themes, it has not yet

See, UNGA resolutions A/RES49/169 of 23 December 1994 and A/RES/50/152 of 21 December 1995. The latter endorses Executive Committee Conclusion No. 78 (XLVI) - 1995.

85 UNHCR Action to Address Statelessness: A Strategy Note, March 2010, available at: https://www.refworld.org/docid/4b9e0c3d2.html

86 UN Secretary General (UNSG), Guidance Note of the Secretary-General: United Nations Assistance to Constitution-making Processes, April 2009, available at: http://www.unhcr.org/refworld/docid/4b8648b52. html.

87 Jo Boyden, 'The Statelessness of the World's Children', (2007) 21 Children \& Society 237. 
been able to achieve consistency in addressing recommendations on the same challenges to all relevant States. ${ }^{88}$ There may be different reasons for this, but it demonstrates the need both for there to be greater awareness among all stakeholders of the issues which the Committee considers to fall within the scope of Article 7 of the CRC and greater capacity of these stakeholders to engage with the Committee on problems that occur in respect of these issues, across different countries. ${ }^{89}$ Given the significant challenges that are faced around the world in realizing children's right to acquire a nationality and ending childhood statelessness, there is real scope for the further, structural promotion of general measures of implementation on this issue. In particular, it must be noted that the Committee has not yet made relevant recommendations on resource allocation, participation of civil society and international cooperation. ${ }^{90}$

Given that the 1954 and 1961 Conventions have been ratified by few States and are not monitored by associated UN treaty monitoring bodies, it is difficult to enforce human rights standards delineated in these two treaties. Furthermore, the treaty bodies mandated to monitor the Convention on the Rights of the Child and the Covenant on Economic, Social, and Cultural Rights, give less focus to the provisions related to statelessness embedded in the two treaties. It is in this context that the role played by civil society actors including Non-Governmental Organizations (NGOs) and National Human Rights Institutions (NHRIs) in promoting the national-level implementation of international human rights norms, including

88 Institute on Statelessness and Inclusion (ISI), Addressing the right to a nationality through the Convention on the Rights of the Child - A Toolkit for Civil Society (ISI, June 2016) 16. child rights becomes crucial. Because of their ability to get close to the affected persons, they are in a better position to understand what barriers exist with respect to the full realization of particular rights and to provide useful information on the impact of laws, policies and practices. They can transmit necessary data on children's access to nationality, standards accepted and interpretations of child rights across national mechanisms to UN bodies. Such information can, in turn, help international monitoring bodies to engage in an effective and wellinformed dialogue with States about the implementation of their international obligations. ${ }^{91}$

\section{CONCLUSION AND SUGESTIONS}

Action 2 of the UNHCR Global Action Plan to End Statelessness 2014-24 calls on States to ensure that no child is born stateless. Fortunately, childhood statelessness is by no means an unsolvable problem. The foregoing discussion reveals that, within the realm of international human rights law, there is broad recognition of the child's right to acquire a nationality, but there are variations in the manner in which this right is formulated. There is also limited guidance on how the right is to be exercised. There is no uniform doctrinal basis for birthright citizenship attribution. In this regard, it is suggested that there shall be a guarantee in every State legislation to the effect that nationality can be acquired on the principle of jus soli (place of birth). Such clear choice for a default jus soli rule and constitutional recognition of the principle for the mandatory granting of nationality to children who would otherwise

$\begin{array}{ll}89 & \text { Ibid. } \\ 90 & \text { Ibid } 18 . \\ 91 & \text { Ibid } 19 .\end{array}$ 
be stateless seems to be the only plausible solution for the problem of childhood statelessness. Here, it is important to note that such a safeguard can be introduced into national law without changing or undermining a State's main doctrinal approach to nationality.

The need for improved data on children's access to nationality, as well as on the scale and impact of childhood statelessness, is an area that must be further prioritized. For this purpose, universal birth registration is a sine qua non. Even though the rules set out in the 1961 Convention will apply regardless of whether a child's birth is registered, registration of birth, which is a right of the child under the CRC and the International Covenant on Civil and Political Rights, will provide a clear evidence for resolving disputes. The requirement under Article 7 of the CRC for registration of births of all refugee children through the same procedure applicable to nationals should also be strictly complied with.

Another measure that is needed to prevent and resolve childhood statelessness is the coordinated, focused and ceaseless efforts on the part of UN Human Rights Bodies. Such Bodies shall strengthen the Universal Periodic Review (UPR) process and ensure simplified State Party reporting to the UN Treaty Bodies including the CRC Committee. They shall also require from State Parties quantitative and qualitative data and shall issue recommendations and doctrinal guidance for addressing gaps in law and practice wherever found necessary. Collective and committed international action involving States, UN Agencies and civil society actors is thus essential to ensure that the right of every child to acquire a nationality is effectively safeguarded and childhood statelessness is eradicated.

\section{REFERENCES}

\section{Books}

Achiron, Marilyn, Nationality and Statelessness - Handbook for Parliamentarians No 22 (Inter Parliamentary Union and UNHCR, $2^{\text {nd }}$ edn, 2014).

Aird, Sarah et al, Stateless Children - Youth Who are Without Citizenship (Youth Advocate Program International, 2014).

Arendt, Hannah., 'The Decline of the NationState and the End of the Rights of Man' in The Origins of Totalitarianism (The World Publishing Company, New York: 1962) 267.

Azzam, Fateh., 'International Law Standards Pertaining to the Arbitrary Deprivation of Nationality' in Institute on Statelessness and Inclusion (ed), The World's Stateless, ISBN: 9789082836660 (ISI, March 2020) 243 Belton, Kristy A., 'Statelessness: A Matter of Human Rights' in Rhoda E HowardHassmann and Margaret WaltonRoberts (eds), The Human Right to Citizenship: A Slippery Concept (University of Pennsylvania Press, 2015) 31, 36-40.

Bhabha, Jacqueline., 'From Citizen to Migrant: The Scope of Child Statelessness in the Twenty-First Century' in Jacqueline Bhabha (ed) Children Without a State - A global Human Rights Challenge (The MIT Press, 2011).

Bhabha, Jacqueline., 'The importance of nationality for children' in Institute on Statelessness and Inclusion (ed.), The World's Stateless Children (Wolf Legal Publishers (WLP), 2017) 112. 
Groot, Gerard-Rene de., Children, their right to a nationality and child statelessness (Cambridge University Press 2014).

Harrington, Catherine., 'Campaigning for gender equality in nationality laws' in Institute on Statelessness and Inclusion, The World's Stateless Children (Wolf Legal Publishers (WLP), January 2017) 499.

Institute on Statelessness and Inclusion (ed), The World's Stateless, ISBN: 9789082836660 (ISI, March 2020)

Institute on Statelessness and Inclusion (ISI), Addressing the right to a nationality through the Convention on the Rights of the Child - A Toolkit for Civil Society (ISI, June 2016).

Institute on Statelessness and Inclusion (ISI), The World's Stateless (Wolf Legal Publishers (WLP), January 2014).

Sokoloff, Constantin and Richard Lewis, Denial of Citizenship: a challenge to human security (European Policy Centre, 2005) 22.

Waas, Laura van., Nationality Matters. Statelessness under International Law, ISBN: 978-90-5095-854-7 (Antwerp/Oxford/Portland, Intersentia, 2008).

Weis, Paul., Nationality and Statelessness in International Law (Kluwer Academic Publishers Group, Dordrecht: 1979) 215.

\section{Journal and Reports}

Batchelor, Carol A., 'Statelessness and the Problem of Resolving Nationality Status' (1998) 10 International Journal of Refugee Law 156.

Blackman, Jeffrey L., 'State Successions and Statelessness: The Emerging Right to an Effective Nationality Under International Law', (1998) 19
Michigan Journal of International Law 1141.

Bodansky, Daniel M., 'The Concept of Customary International Law' (1995) 16(3) Michigan Journal of International Law 667.

Boyden, Jo., 'The Statelessness of the World's Children', (2007) 21 Children \& Society 237.

Doek, Jaap., 'The CRC and the Right to Acquire and Preserve a Nationality' (2006) 25 Refugee Survey Quarterly 26-32.

Foster, Michelle et al, 'Part One: The Prevention and Reduction of Statelessness in Australia - An Ongoing Challenge' (2017) 40 Melbourne University Law Review 456, 458.

Frelick, B and M. Lynch, 'Statelessness: a forgotten human rights crisis', (2005) 24 Forced Migration Review 65. <https://www.fmreview.org/sites/fmr/f iles/FMRdownloads/en/sudan/frelicklynch.pdf>

Leclerc, Philippe and Rupert Colville, 'In the shadows', (2007) 147 Refugees 6.

Lynch, Maureen and Melanie Teff, 'Childhood statelessness', (2009) 32 Forced Migration Review 32.

Weis, Paul., 'The United Nations Convention on the Reduction of Statelessness' (1961) 11 International and Comparative Law Quarterly 1073.

Worster, William Thomas., The Obligation to Grant Nationality to Stateless Children Under Customary International Law (2019) 27(3) Michigan State International Law Review 441.

\section{Regulations}

Convention on Certain Questions Relating to the Conflict of Nationality Laws, 
opened for signature 12 April 1930, 179 LNTS 89 (entered into force 1 July 1937) art 1.

Convention on the Elimination of All Forms of Discrimination Against Women (1979), 1249 UNTS 13 (entered into force 3 September 1981).

Convention on the Reduction of Statelessness, opened for signature 30 August 1961, 989 UNTS 175 (entered into force 13 December 1975).

Convention on the Rights of the Child, (1989)

1577 UNTS 3 (entered into force 02 September 1990).

Convention Relating to the Status of Refugees, (1951) 189 UNTS 137 (entered into force 22 April 1954).

Convention Relating to the Status of Stateless Persons, (1954) 360 UNTS 117 (entered into force 06 June, 1960).

Declaration on the Human Rights of Individuals Who are not Nationals of the Country in Which They Live, GA Res 40/144 (13 December 1985).

Human Rights Committee, General comment No. 17: Article 24 (Rights of the child) (29 September 1989).

Human Rights Committee, General Comment No. 18: Non-Discrimination, UN Doc CCPR/C/GC/18 (10 November 1989).

Inter-American Program for Universal Civil Registry and the "Right to Identity", AG/RES. 2362 (XXXVIII-O/08) (03 June 2008).

International Convention on the Elimination of All Forms of Racial Discrimination (21 December 1965) 660 UNTS 195 (entered into force 04 January 1969).

International Convention on the Protection of the Rights of all Migrant Workers and Members of Their Families: A/RES/45/158 (18 December 1990).
International Covenant on Civil and Political Rights (1966) 999 UNTS 171 (entered into force 23 March 1976).

International Law Commission, Identification of Customary International Law: Text of the Draft Conclusions Provisionally Adopted by the Drafting Committee, UN Doc. A/CN.4/L.872

(2016).

$\langle$ http://legal.un.or/lc>

Organization of African Unity (OAU), African Charter on the Rights and Welfare of the Child, 11 July 1990, CAB/LEG/24.9/49 (entered into force 29 November 1999).

Organization of American States (OAS), American Convention on Human Rights, "Pact of San Jose", Costa Rica, 22 November 1969 (entered into force 18 July 1978).

Organization of the Islamic Conference (OIC), Covenant on the Rights of the Child in Islam, June 2005, OIC/9IGGE/HRI/2004/Rep.Final (June 2005).

Prevention and Reduction of Statelessness and Protection of Stateless Persons in the Americas, AG/RES. 2826 (XLIVO/14) (04 June 2014).

UN General Assembly, Resolution 50/152: Office of the United Nations High Commissioner for Refugees (09 February 1996), para. 16.

U.N. Secretary-General (UNSG), Arbitrary Deprivation of Nationality: Report of the Secretary-General, U.N. Doc. A/HRC/10/34 (Jan. 26, 2009).

UN Secretary General (UNSG), Guidance Note of the Secretary-General: United Nations Assistance to Constitutionmaking Processes, April 2009 <http://www.unhcr.org/refworld/docid /4b8648b52.html>.

UNHCR Action to Address Statelessness: A Strategy Note, March 2010 
<https://www.refworld.org/docid/4b9e $0 \mathrm{c} 3 \mathrm{~d} 2 . \mathrm{html}$.

Universal Declaration of Human Rights, GA Res 217A (III), UN GAOR, $3^{\text {rd }}$ sess, $183^{\text {rd }}$ plen $\mathrm{mtg}$, UN Doc A/810 (10 December 1948).

\section{Cases}

Advisory Opinion No. 4, Nationality Decrees Issued in Tunis and Morocco (1923), Permanent Court of International Justice (7 February 1923). $<$ https://www.refworld.org/cases,PCIJ ,44e5c9fc4.html>.

Trop v. Dulles, 356 U.S. 86 (1958) $<$ https://www.loc.gov/item/usrep3560 86/>.

Liechtenstein v. Guatemala (Nottebohm Case) [1955] ICJ Rep 1 (6 April 1955). Mennesson v. France (26 June 2014), European Court of Human Rights $<$ http://acerwc.org/?wpdmdl=8606 $(\mathrm{FR})>$.

Yean and Bosico v. Dominican Republic (8 September 2005), Inter-American Court of Human Rights <http://www.refworld.org/docid/44e4 97d94.html.>.

\section{Internets}

Institute on Statelessness and Inclusion (ISI), Statelessness in numbers: An overview and analysis of global statistics (2018) $<$ https://files.institutesi.org/ISI_statisti cs_analysis_2018.pdf>.
Open Society Justice Initiative, Children's right to a nationality (June, 2011) <https://www.justiceinitiative.org/publ ications/fact-sheet-childrens-rightnationality>

UN High Commissioner for Refugees (UNHCR), Background Note on Gender Equality, Nationality Laws and Statelessness 2020 (14 July 2020) $<$ https://www.refworld.org/docid/5f0d 7b934.html>.

UN High Commissioner for Refugees (UNHCR), Global Action Plan 201424 to End Statelessness (2014)

<https://www.unhcr.org/statelesscampaign2 014/Global-Action-Plan-eng.pdf> .

UN High Commissioner for Refugees (UNHCR), Global Trends - Forced Displacement <https://www.unhcr.org/5b27be547.pd f>

UN High Commissioner for Refugees, Guidelines on the Definition of "Stateless Person" in Article 1(1) of the 1954 Convention relating to the Status of Stateless Persons, (2012) <http://www.unhcr.org/refworld/docid /4f4371b82.html>.

Worster, William Thomas., The Presumption of Customary International Law: A Case Study of Child Statelessness (December 21, 2017) <http://dx.doi.org/10.2139/ssrn.30919 12>. 